\title{
Penulis Loh Batu Kedua Sepuluh Perintah Allah:
} Analisis terhadap Keluaran 34:1,28

\author{
The Author of the Second Tablets of the Ten Commandments: \\ Analysis Textual of Exodus 34:1, 28
}

\section{Rubyantara Jalu Permana}

Mahasiswa Pascasarjana Teologi, Seminari Theologia Baptis Indonesia (STBI) Semarang rubyantarajp@gmail.com

\section{Sonny Eli Zaluchu}

Seminari Theologia Baptis Indonesia (STBI) Semarang sonnyzaluchu stbi.ac.id

\begin{tabular}{|c|c|}
\hline Article Info & Abstract \\
\hline $\begin{array}{l}\text { Submitted: Mei 9, } 2020 \\
\text { Review: Mei 11, } 2020 \\
\text { Accepted: Mei 25, } 2020\end{array}$ & $\begin{array}{l}\text { Differences in Exodus } 34 \text { verses } 1 \text { and } 28 \text { cause the inerrancy of the Bible to } \\
\text { be questioned. The assumption arises that the difference becomes a gap to } \\
\text { prove inconsistencies in the biblical narrative so that it does not deserve to be } \\
\text { called a word of God. This study aims to analyze these differences using a } \\
\text { theological approach followed by a hermeneutic analvsis of the two texts. }\end{array}$ \\
\hline $\begin{array}{l}\text { Keywords: } \\
\text { the Ten Commandment, } \\
\text { Moses, Exodus, tablets, } \\
\text { God's Law }\end{array}$ & $\begin{array}{l}\text { Research on the sources involved. The conclusion is that the text in Exodus } 34 \\
\text { verse } 28 \text { legitimizes the intent and purpose contained in verse } 1 \text {, that God } \\
\text { Himself wrote the laws on the stone tablets, both the first and the second } \\
\text { tablets. This analysis confirms that the search for the meaning of a text in } \\
\text { context does not only involve an analytical approach. }\end{array}$ \\
\hline
\end{tabular}

[Perbedaan dalam Kitab Keluaran 34 ayat 1 dan 28 menyebabkan inerancy Alkitab dipertanyakan. Muncul anggapan yang mengatakan bahwa perbedaan tersebut menjadi celah untuk membuktikan adanya inkonsistensi di dalam narasi Alkitab sehingga tidak layak disebut sebagai firmn Allah. Penelitian ini bertujuan menganalisis perbedaan tersebut dengan menggunakan pendekatan teologis yang diikuti dengan analisis hermeneutik terhadap kedua teks tersebut. Penelitian terhadap sumber ikut dilibatkan. Kesimpulannya adalah teks di dalam Keluaran 34 ayat 28 melegitimasi maksud dan tujuan yang terdapat di dalam ayat 1, bahwa Allah sendiri yang menulis hukum hukumNya pada loh batu tersebut, baik loh pertama maupun loh kedua. Analisis ini menegaskan bahwa pencarian makna teks dalam konteks tidak hanya melibatkan pendekatan analitis.] 


\section{PENDAHULUAN}

$\mathrm{D}$ alam kapasitasnya sebagai firman Allah, umat kristiani memegang sebuah prinsip bahwa Alkitab tidak mengandung kesalahan atau innerant. Chicago Statement yang dibuat untuk menegaskan sifat ineransi Alkitab dalam membendung arus liberal dan neo ortodoks ke dalam ajaran gereja, ditutup dengan sebuah kalimat kunci berupa pengakuan deklaratif yang menegaskan ketaksalahan Alkitab karena berasal dari perkataan Allah, "We affirm that what Scripture says, God says." Pernyataan Chicago tersebut dirumuskan oleh lebih dari 200 pemimpin injili dari seluruh dunia dalam konferensi yang diadakan oleh Dewan Internasional tentang Ineransi Alkitab di kota Chicago pada Oktober $1978 .{ }^{1}$

Keyakinan yang sangat mendasar ini membawa dampak yang signifikan di dalam cara orang Kristen membaca dan memperlakukan dan merespon isi Alkitab serta merefleksikannya di dalam kehidupan sehari-hari. Teolog seperti Ficket misalnya, menyatakan bahwa Alkitab bukan sekedar tulisan sastra kuno. Baginya Alkitab berisi Firman Allah dan firman Tuhan itu sendiri secara keseluruhan. ${ }^{2}$ Kendatipun terdiri dari banyak buku yang ditulis oleh banyak penulis, menurut White, isinya saling relevan, signifikan dan tidak saling kontradiktif sebab diinspirasikan oleh Tuhan sendiri. ${ }^{3}$ Padahal kenyataannya, proses penulisan dan penyusunan hingga menjadi kanon, mencakup rentang waktu ratusan tahun. Isinya teruji dan tetap konsisten. Tidak ada alasan untuk tidak mempercayai isinya. ${ }^{4}$

Di sisi lain, keyakinan atas Alkitab sebagai innerant material, tidak pernah lepas dari berbagai gugatan dan serangan. Isinya terus dipertanyakan dan dipertentangkan baik di kalangan intelektual Kristen sendiri maupun penganut agama lain. ${ }^{5}$ Penelitian Darojat misalnya, mengindentifikasi sejumlah hal sebagai aspek meragukan di dalam Taurat. Dalam artikelnya berjudul, "Ketidakaslian Kitab Taurat Dalam Perjanjian Lama dan Empat Injil dalam Perjanjian Baru (Studi terhadap Proses Penulisannya)" dikatakannya repetisi isi dan narasi yang bersifat pengulangan di dalam kitab yang berbeda dilihatnya tidak sinkron. Darojat juga menyoroti adanya penyebutan nama Tuhan yang berbeda di dalam kitab yang sama dan catatan mengenai mujizat yang dianggap tidak logis dan tidak mungkin terjadi. ${ }^{6}$

Memperlakukan Alkitab dan isinya sebagai karya sastra adalah salah satu persoalan yang membenturkan keyakinan kaum Injili dengan para teologi Kristen penganut kritik modern. Demikian juga gugatan demi gugatan dari lingkup eksternal yang bersifat mempertanyakan keabsahan isi dan cerita Alkitab. Salah satu yang paling menonjol adalah tudingan inkonsistensi isi. Akibatnya, atmosfir keraguan terhadap Alkitab terbentuk dan selalu mewarnai sejarah ineransi itu sendiri. Sebagai contoh, dalam bukunya, Ridenour menuliskan beberapa pertanyaan yang umum ditanyakan oleh kaum awam, seperti pertanyaan "bukankah Alkitab itu banyak salahnya?" ditambah dengan sedang maraknya pemahaman-pemahaman kebenaran individu hingga timbul pernyataan-pernyataan yang menentang kebenaran Alkitab. Seperti Long, di dalam bukunya,

1 “The Chicago Statement on Biblical Inerrancy," Master's Seminary Journal 1, no. Spring (2014): $1-10$.

${ }^{2}$ Harold L. Ficket, Kepercayaan Kaum Baptis: Sebuah Pedoman (Semarang: Seminari Theologia Baptis Indonesia, 1985).

${ }^{3}$ James Emery White, Can We Trust The Bible? (Downers Grove: Intervarsity Press, 2010).

${ }^{4}$ Craig L. Blomberg, Can We Still Believe The Bible: An Evangelical Engagement with Contemporary Questions (Grand Rapids: Brazos Press, 2014).

${ }^{5}$ Kenneth Cragg, "Being Christian and Being Muslim: A Personal Debate," Religion 10, no. 2 (1980): 196-208.

${ }^{6}$ M. Darojat Ariyanto, "Ketidakaslian Kitab Taurat Dalam Perjanjian Lama Dan Empat Injil Dalam Perjanjian Baru (Studi Terhadap Proses Penulisannya)," Ishraqi 4, no. 1 (2008), https://publikasiilmiah.ums.ac.id/bitstream/handle/11617/1002/3. M. Darojat Ariyanto.pdf? sequence $=1$ \&isAllowed $=\mathrm{y}$.

${ }^{7}$ Fritz Ridenour, Dapatkah Alkitab Dipercaya (Jakarta: BPK Gunung Mulia, 2000). 
meragukan kebenaran kisah Nuh di dalam Perjanjian Lama melalui usahanya menyandingkan narasi itu dengan penjelasan ilmiah. ${ }^{8}$

Ketidakpahaman pembaca akibat kurangnya pengetahuan akan isi Alkitab adalah salah satu faktor utama yang menyebabkan timbulnya keraguan akan Alkitab. Ketidaksinkronan cerita di dalam narasi, ketidaksesuaian informasi, kesalahan-kesalahan salinan dan hal-hal menyangkut peristiwa yang tidak masuk akal atau menabrak kaidah ilmiah, menjadi sejumlah indikator yang sering diangkat ke permukaan untuk mengkritik isi Alkitab itu sendiri.

Dalam tulisan ini, penulis akan membahas tudingan inkonsistensi terhadap salah satu narasi Alkitab di kitab kejadian yang membahas peristiwa di gunung Sinai ketika Musa menerima dua loh batu berisi hukum Tuhan. Rujukannya adalah narasi dalam Kitab Keluaran 34:1 (ITB) "Berfirmanlah TUHAN kepada Musa: "Pahatlah dua loh batu sama dengan yang mula-mula, maka Aku akan menulis pada loh itu segala firman yang ada pada loh yang mula-mula, yang telah kaupecahkan." Pada ayat tersebut dinyatakan bahwa "Aku", yang adalah TUHAN Allah, yang akan menuliskan segala firman pada loh batu yang baru. Namun, pada pasal yang sama, pada ayat yang berbeda yakni di ayat 28 tertulis pernyataan lain. "Dan Musa ada di sana bersama-sama dengan TUHAN empat puluh hari empat puluh malam lamanya, tidak makan roti dan tidak minum air, dan ia menuliskan pada loh itu segala perkataan perjanjian, yakni Kesepuluh Firman”. Pada ayat tersebut tertulis bahwa yang menulis pada loh batu itu ialah Musa. Perbedaan yang sangat menyolok ini memicu tudingan inkonsistensi baik yang ditujukan kepada penulis Keluaran maupun pada Tuhan sendiri yang berada di pusat cerita itu. Ineransi Alkitab dipertanyakan kembali, khususnya mengeni keabsahan sumber. Dari sini muncul sebuah pertanyaan, siapakah yang sesungguhnya menulis di loh batu tersebut? Problematikan terhadap perbedaan teks tersebut akan dianalisis di dalam paper melalui pendekatan hermeneutik.

\section{METODE}

Pendekatan kuantitatif ${ }^{9}$ di dalam paper ini sepenuhnya bertumpu pada metode hermeneutik. ${ }^{10}$ Alkitab Keluaran 34 ayat 1 dan ayat 28 (TB). Kedua ayat tersebut disandingkan berikut ini:

${ }^{1}$ Berfirmanlah TUHAN kepada Musa: "Pahatlah dua loh batu sama dengan yang mula-mula, maka Aku akan menulis pada loh itu segala firman yang ada pada loh yang mula-mula, yang telah kaupecahkan.

${ }^{28}$ Dan Musa ada di sana bersama-sama dengan TUHAN empat puluh hari empat puluh malam lamanya, tidak makan roti dan tidak minum air, dan ia menuliskan pada loh itu segala perkataan perjanjian, yakni Kesepuluh Firman.

Langkah pertama adalah membuat analisis gramatikal pada masing-masing teks, kemudian menyajikan hasil tafsiran yang dilengkapi dengan beberapa sumber yang relevan dari berbagai commentary. ${ }^{11}$ Pandangan teologis dari beberapa komentator Alkitab juga dipergunakan sebagai langkah analisis sebagaimana dijelaskan Baker dalam sebuah tinjauan literatur. ${ }^{12}$ Semua bahan ini diarahkan dengan berbagai pendekatan yang memperlihatkan bahwa ayat 1 dan 28 di dalam Keluaran 34 tidak bertentangan.

${ }^{8}$ Jason Long, Biblical Nonsense: A Review of The Bible for Doubting Christians (Lincoln: iUniverse, 2005).

9 Sonny Eli Zaluchu, "Strategi Penelitian Kualitatif Dan Kuantitatif Di Dalam Penelitian Agama,"

Evangelikal: Jurnal Teologi Injili dan Pembinaan Warga Jemaat 4, no. 1 (2020): 28-38.

${ }^{10}$ David L. Rennie, "Qualitative Research as Methodical Hermeneutics," Psychological Methods 17, no. 3 (2012): 385-398.

${ }^{11}$ Queency Christie Wauran, "Kajian Biblika Kecemburuan Allah Terhadap Penyembahan Berhala Berdasarkan Keluaran 20:4-6,” Jaffray 13, no. 2 (2015): 36.

12 Joy Don Baker, "The Purpose, Process, and Methods of Writing a Literature Review," AORN Journal 103, no. 3 (2016): 265-269. 


\section{PEMBAHASAN}

\section{Tinjauan Gramatikal}

Musa menerima perintah langsung dari Tuhan menurut ayat 1 untuk membuat dua loh batu baru sebagai pengganti yang pertama yang telah pecah. Kemudian, dikatakan oleh TUHAN: "..maka Aku akan menulis pada loh batu itu segala firman...". Dalam terjemahan tersebut sudah mengindikasikan bahwa "Aku" lah yang akan melakukan aktivitas menulis di atas loh batu itu. Di

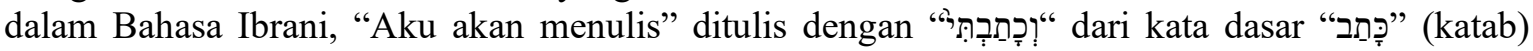
yang berarti menulis. Kata קַָּ pada ayat tersebut ditulis dalam bentuk kata kerja qal perfect $1^{\text {st }}$ person common singular. ${ }^{13}$ LAI menerjemahkan sangat tepat melalui kalimat, "Aku akan...". Dan, bentuk orang pertama tunggal ( $1^{\text {st }}$ person common singular) menegaskan tentang tindakan orang pertama, yang mengucapkan kalimat tersebut. Bentuk kata kerja yang sama dapat ditemukan di dalam Yeremia 31:33 "Aku akan menjadi Allah mereka...". Kalimat "Aku akan menjadi" ditulis

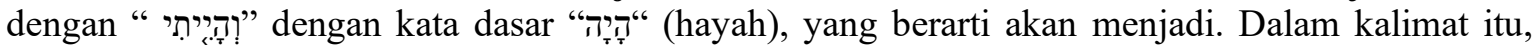
karena Allah sendiri yang berbicara maka dapat diartikan secara harfiah bahwa "Aku", yakni Allah sendiri, yang akan menjadi Allah atas mereka, bukan Yeremia, walaupun Allah sedang berbicara melalui Yeremia. Kesimpulan Cole senada. Melihat sifat kata kerja yang ada, maka dalam kasus penulisan dua loh batu di atas tersebut, dikerjakan sendiri oleh tangan Tuhan. ${ }^{14}$ The Orthodox Jewish Bible menguatkan kesimpulan tersebut. Ayat yang sama ditulis sebagai berikut. "And Hashem said unto Moses, Chisel thee two Luchot Avanim like the first ones, and I will write upon these Luchot the divariem that were on the Luchot HaRishonim, which thou broke."15 Artinya, bukan orang lain ataupun Musa, melainkan tangan Tuhan sendiri yang menulis di batu tersebut.

Selanjutnya adalah pada ayat 28 kitab yang sama. Tertulis di dalam Alkitab Bahasa Indonesia Terjemahan Baru "Dan Musa ada di sana bersama-sama dengan Tuhan...dan ia menuliskan pada loh itu segala perkataan perjanjian itu..." Analisis tata bahasa memberikan arti harafiah bahwa subjek kalimat tersebut adalah Musa, yang sedang berada di atas gunung Sinai dan

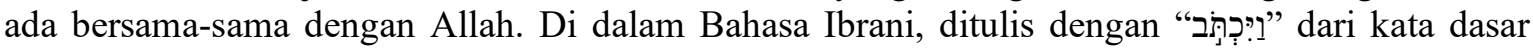

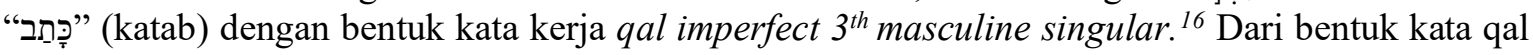
consecutive imperfect yang digunakan dalam teks terindikasi bahwa tindakan tersebut dikerjakan oleh Musa sendiri. Bukan orang lain atau individu lain, termasuk TUHAN. ${ }^{17}$ Pemakaian bentuk orang ketiga maskulin tunggal juga mengindikasikan Musa yang melakukan penulisan ini sedang diceritakan oleh narator kepada pembaca. Naskah The Orthodoc Jewish Bible juga mendukung pengertian yang sama. "And he was there with Hashem arba'im yom and arba'im lailah; he did neither eat lechem, nor drink mayim. And he wrote upon the Luchot the Divrei HaBrit (Words of the Covenant), the Aseres Hadevarim (Ten Commandments)." Kata 'he wrote' disitu merujuk pada Musa.

\section{Diskusi}

Hasil pemeriksaan gramatikal terhadap kedua ayat tersebut memperlihatkan dua pernyataan yang memang kontradiktif. Pada ayat pertama, penulis loh batu adalah Tuhan sendiri sedangkan pada ayat yang keduapuluh delapan, terlihat bahwa Musa penulisnya. Kendatipun pendekatan gramatikal penting untuk mengangkat makna, dalam sebuah proses hermeneutik, beberapa unsur lain penting dan harus diperhatikan di dalam rangka penafsiran. Salah satunya adalah sumber teks yang ikut memberikan pengaruh di dalam penentuan makna. Khususnya di dalam kitab-kitab Pentatuech yang secara tradisi merujuk Musa sebagai penulisnya, jika dicermati secara redaksional,

\footnotetext{
${ }^{13}$ John Joseph Owens, Analytical Key to the Old Testament. Volume 1. (Grand Rapids, Michigan: Baker Books, 1998).

${ }^{14}$ Alan Cole, Exodus: An Introduction and Commentary, First. (Leicester, England: The Tyndale Press, 1973).

15 AFII, The Orthodox Jewish Bible, 4th ed. (New Yok: AFI International Publisher, 2011).

${ }^{16}$ Owens, Analytical Key to the Old Testament. Volume 1.

${ }^{17}$ E. J. Revell, "Stress and the WAW 'Consecutive' in Biblical Hebrew," Journal of American Oriental Society 104, no. 3 (1984): 8.
} 
maka akan terlihat perbedaan kontras bahwa sesungguhnya kitab-kitab tersebut disusun sebagai layer-layer dari sumber yang berbeda dan kemudian muncul di dalam bentuk finalnya, kitab Keluaran. Dalam penelitiannya tetang hal ini, Rendtorff merujuk keberadaan empat kelompok peredaksi di dalam teks kitab Musa yang jika tidak hati-hati, akan mengacaukan pemahaman saat melakukan kritik. Keempat peredaksi tersebut adalah kaum Yahwista (Y), Elohista (E), Deuteronomist (D) , dan Kelompok Para Imam (P). Keempatnya memiliki ciri khasnya masingmasing di dalam menyatakan narasinya di dalam teks. ${ }^{18}$ Dengan kata lain, perbedaan ini dapat diselesaikan dengan pendekatan kritik teks. Tujuan kritik ini adalah menyingkap misteri dibalik perubahan, pergeseran atau bahkan potensi kesalahan yang mungkin dibuat oleh para penyalin atau editor Alkitab ketika proses penyalinan berlangsung. Kesalahan berupa korupsi kata, peredaksian ulang, atau pergeseran makna dapat saja terjadi akibat pengaruh situasi eksternal yang melatarbelakangi masa hidup para penyalin. ${ }^{19}$

Sitompul \& Beyer mengusulkan bahwa untuk melakukan kritik teks, pembaca diwajibkan meneliti asal usul teks hingga ke sumber tertua dan menganalisis perubahan tekstual sehingga terjadi kesalahan. Sekaligus penafsir dituntut menelaah alasan dibalik perubahan tersebut. ${ }^{20}$

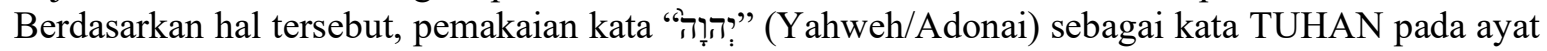
pertama menyatakan bahwa bagian teks tersebut diredaksi oleh kaum Yahwista. ${ }^{21}$ Kaum Yahwista selalu menggambarkan Allah secara manusiawi (anthropomorphisme) sebagai ciri khas. ${ }^{22}$ Itulah sebabnya di dalam ayat pertama, Allah digambarkan menulis di atas batu sebagaimana kemampuan yang sama dimiliki setiap manusia.

Namun, penjelasan tersebut masih menyisakan perbedaan dengan makna di dalam narasi ayat 28 yang terang-terangan menyatakan Musa menulisnya. Driver memberikan sebuah solusi. Menurutnya ada dua jenis loh batu. Satu milik dan ditulis oleh Allah dan satu milik dan ditulis oleh Musa. ${ }^{23}$ Namun, tafsiran tersebut sudah memperlihatkan kelemahan teologis sebab tidak ada penguatan di dalam teks yang menyatakan kepemilikian Musa atas batu yang ditulisnya. ${ }^{24}$

Cole mengusulkan sebuah jalan tengah teologis. Menurutnya narrator pada pasal 34 tidak mengindikasikan adanya masalah antara ayat 1 dengan ayat 28. Secara teologis, tujuan yang lebih utama adalah, ada hukum Tuhan yang dinyatakan oleh Allah kepada umat-Nya melalui dua loh batu. Melalui pengertian ini, perbedaan teks ayat 1 dan ayat 28 seharusnya tidak bermasalah, karena peristiwa tersebut sedang dinyatakan melalui cara lain oleh narator. Taurat sebagai ekspresi hati dan pikiran Allah dinyatakan kepada Musa pada saat menulis hukum itu. ${ }^{25}$ Dengan kata lain, pengertian, hati dan tangan Musa dikendalikan oleh Tuhan yang saat itu sedang bersama-sama dengan Dia. Itulah sebabnya, keabsahan kepenulisan Tuhan atas kedua loh batu tersebut, tidak perlu diragukan lagi. Pertentangan harafiah akibat perbedaan pendekatan tidak mengubah makna teologis dari narasi itu sendiri.

Analisis yang lebih kuat datang dari pemikiran Hamilton. Menurutnya, persoalan yang terjadi di dalam ayat 28 dapat diselesaikan dengan memahami sifat gramatikal bahasa Ibrani mengenai pergeseran subjek. Analisis lebih tepat dimulai dari ayat 27 yang mengatakan,

${ }^{18}$ Rolf Rendtorff, "The 'Yahwist' as Theologian? The Dilemma of Pentateuchal Criticism," Journal for the Study of the Old Testament 1, no. 3 (1976): 2-10.

19 J. K. Elliott and Bruce M. Metzger, "The Text of the New Testament. Its Transmission, Corruption and Restoration," Novum Testamentum 36, no. 1 (1994): 97.

${ }^{20}$ A.A. Sitompul and Ulrich Beyer, Metode Penafsiran Alkitab, 14th ed. (Jakarta: BPK Gunung Mulia, 2009).

${ }^{21}$ Rick Wright, Linguistic Evidence for the Pre-Exilic Date of the Yahwistic Source, first. (London: T\&T Clarck, 2005).

${ }^{22}$ Christoph Levin, "The Yahwist: The Earliest Editor in the Pentateuch," Journal of Biblical

Literature 126, no. 2 (2007): 209-230. Press, 1953).

${ }^{23}$ S. R. Driver, Book of Exodus, 4th ed. (Cambridge: The Syndics of The Cambridge University

${ }^{24}$ David L. Baker, "Ten Commandments, Two Tablets: The Shape of The Decalogue," Themelios 30, no. 3 (2005): 17 .

${ }^{25}$ Cole, Exodus: An Introduction and Commentary. 
Berfirmanlah TUHAN kepada Musa: "Tuliskanlah segala firman ini, sebab berdasarkan firman ini telah Kuadakan perjanjian dengan engkau dan dengan Israel." Jika Musa adalah penulis yang dimaksud dalam ayat 27, maka posisi subjek ditempati oleh Tuhan, sebagaimana dimaksud dalam ayat 28. Hamilton mengutip pendapat Moberly (1983: 103) untuk menjelaskan alasannya. Jika Musa adalah penulis yang dimaksud dalam ayat 27 , Tuhan harus menjadi subjek sebagaimana dimaksud dalam ayat $28 \mathrm{~b}$. Ada beberapa alasan untuk ini.

Pertama, "dia" ada di sana, "dia" tidak makan, "dia" tidak minum dan "dia" menulis. Secara logis, orang dapat berkesimpulan bahwa "dia" dari tiga subjek pertama dari kata kerja itu adalah Musa, maka kemungkinan besar Musa juga subjek dari "dia" yang keempat, yang di dalam teks dikatakan 'menulis'. Ini belum tentu demikian. Bahasa Ibrani dapat menggeser subjek kata kerja orang ketiga dalam kalimat yang sama tanpa menunjukkan dengan jelas siapa yang dimaksud. "Dia" yang 'menulis' tersebut bisa Musa atau yang lain. Lihat misalnya kasus dalam 34: 5. "Turunlah TUHAN ("Dia") dalam awan, lalu berdiri di sana dekat Musa ("dia") serta menyerukan nama TUHAN ("dia). "Dia" yang pertama Tuhan bergeser ke pengertian orang lain (Musa) dalam merujuk "dia" yang kedua. Sedangkan "dia" yang ketiga di dalam teks tersebut tidak jelas siapa.

Alasan berikutnya adalah, saat menjadikan Tuhan subjek dari kata kerja dalam ayat $28 \mathrm{~b}$ maka ayat itu dapat dijadikan klaim yang konsistem terhadap ayat 34: 1 (Bandingkan juga dengan teks Ulangan 10: 4). Ketiga, dalam ayat 27 Tuhan memberi tahu Musa untuk menuliskan "kata-kata ini" sebanyak dua kali, sementara pada ayat 28 menggunakan ungkapan lain, "kata-kata perjanjian - Sepuluh Firman." Jika Musa adalah penulis dalam ayat 28b, maka orang akan mengharapkan bahasanya bergema di ayat 27, yaitu, "Dan dia (Musa) menulis kata-kata ini." Kenyataannya tidak demikian. Keempat, catatan dalam ayat 28a (puasa Musa empat puluh hari) kemungkinan besar akan mengikuti ayat $28 \mathrm{~b}$ daripada mendahuluinya. Jika Musa adalah penulis dalam ayat 27 dan $28 \mathrm{~b}$ seharusnya penulis kitab ini tidak perlu memecah dua referensi dan kegiatan yang sama (menulis) ke dalam ayat yang berbeda. ${ }^{26}$

Pendekatan melalui analisis kontekstual mendukung analisis tersebut. Keluaran 34:28 sebetulnya lanjutan dari ayat-ayat sebelumnya. Mulai dari ayat 10 sampai 27, Alkitab mencatat bahwa Tuhan berbicara kepada Musa. Deskripsi ayat memperlihatkan bahwa Tuhan sedang menjelaskan ketentuan dan aturan dari hukum-hukum ilahi yang harus ditaati seara harafiah dan mutlak oleh orang Israel. Ayat 27 adalah sebuah penutupan yang menegaskan bahwa Musa bertugas menulis semua penjelasan Tuhan tersebut. "Tuliskanlah segala firman ini, sebab berdasarkan firman ini telah Kuadakan perjanjian dengan engkau dan dengan Israel." Dengan kata lain, ayat 27 memberi informasi akurat bahwa Musa mencatat semua perkataan hukum dari Tuhan yang disebutkan mulai dari ayat 10. Proses itu berlangsung berhari-hari. Ayat 28 memberikan keterangan bahwa Musa bersama-sama Tuhan hingga empat puluh hari, empat puluh malam tanpa makan dan minum. Kekuatan supernatural Tuhan berlaku atas Musa sehingga mampu berpuasa dan bertahan sangat lama di atas gunung Sinai (Keluaran 34:28). Perbedaan yang muncul di akhir teks ayat 28, tidak mendukung konteks narasi sebagaimana terdapat di dalam Ulangan 10:2 sebagai konteks jauh.

Narasi di dalam Ulangan 10:2 berbunyi, "maka Aku akan menuliskan pada loh itu firmanfirman yang ada pada loh yang mula-mula yang telah kaupecahkan itu, kemudian letakkanlah kedua loh ke dalam tabut itu." Kalimat tersebut selaras dengan yang ada di dalam Keluaran 34:1. Kedua catatan menyatakan dengan kuat bahwa Tuhanlah yang menulis pada kedua loh batu tersebut dengan jari-Nya sendiri. Apabila ayat 28b dimengerti sebagai perbuatan tagnan Musa terdapat kesulitan di dalam mencari dukungan kontekstualnya untuk narasi dengan tema yang sama. Dengan kata lain, perbedaan yang terkandung di dalam Keluaran 34:28 tidak didukung oleh pendekatan konteks. Itulah sebabnya dipahami bahwa Musa dan Tuhan sama-sama menulis sesuatu di atas gunung Sinai. Bagian Musa mencakup ayat 10 sampai dengan 27. Adapun sepuluh hukum di bagian ayat $28 \mathrm{~b}$ tetap menjadi bagian Tuhan untuk penulisannya.

${ }^{26}$ Victor P. Hamilton, Exodus - An Exegetical Commentary (Grand Rapids, Michigan: Baker Academic, 2011). 
Jalan tengah lain diusulkan oleh beberapa teolog dengan meminjam teori pendiktean dalam ineransi. Dilihat dari sudut pandang manapun, Tuhan tetap sebagai oknum dan pribadi yang dianggap sebagai penulis utama di dalam kedua kisah tersebut. Narasi yang pertama mendeskripsikan bahwa tangan Tuhan ikut terlibat sedangkan pada narasi kedua, Tuhan menggunakan akal pikiran dan tangan Musa untuk menulis hukumnya, sebagaimana proses yang dialami oleh para penulis Alkitab. Di dalam teori inspirasi Alkitab hal itu dikenal sebagai verbal dictation theory. ${ }^{27}$ Menurut teori ini, para penulis mencatat kata-kata Tuhan persis seperti yang diucapkanNya. Partisipasi penulis berupa gaya tulisan, kepribadian dan opini pribadi, tidak ikut melakukan intervensi di dalam proses pencatatan. Semata-mata penulis seperti robot yang dikendalikan oleh Tuhan untuk menuruti perintahNya. Dalam proses ini penulis secara mekanis merekam kata-kata suci, seperti seorang yang sedang melakukan transkrip wawancara atau seorang sekretaris, semua kata ditulis persama sama dengan yang diucapkan. Pandangan ini terbatas pada ide bahwa Allah hanya mendikte isi kedua loh batu itu kepada Musa, sedangkan untuk keseluruhan kitab suci tetap mengarah pada plenary verbal inspiration. ${ }^{28}$

Akhirnya sebuah solusi muncul dari pemikiran Yahudi. Hal ini patut dipertimbangkan mengingat teks di atas kedua loh batu tersebut dianggap sebagai teks suci (huruf suci) yang ditulis oleh Tuhan sendiri. Dalam hal ini, persepektif Yahudi perlu menjadi pegangan utama karena teks di dalam kitab Taurat adalah sebuah naskah Yahudi yang otentik di dalam isi dan penyajiannya. Rabi Meir Simchah dari Dvinsk menafsirkan bahwa ukiran awal pada loh batu yang kedua dilakukan oleh Musa. Tetapi hasilnya tidak sesempurna yang pertama karena ditulis oleh tangan manusia yang terbatas di dalam melaksanakan tugas suci tersebut. Tuhan menyempurnakan dan menyelesaikan pekerjaan yang telah dimulai Musa. Hasil ukirannya ditulis ulang oleh Tuhan sehingga teologi Yahudi meyakini bahwa hasilnya menjadi persis seperti pada loh batu yang pertama. Musa menggoreskan kemudian Tuhan menyempurnakannya. ${ }^{29}$

\section{KESIMPULAN}

Dapat disimpulkan bahwa kedua loh batu ditulis oleh tangan Tuhan sendiri. Perbedaan yang muncul secara literal dari teks Keluaran 24 ayat 1 dan ayat 28 tidak mengubah makna teologis bahwa kedua teks tersebut sedang menyajikan bagaimana Tuhan menyampaikan hukum kepada umat-Nya melalui dua loh batu. Hasil analisis terhadap kedua teks ternyata memberikan gambaran bahwa ayat 28 mengklaim kebenaran ayat 1 di dalam kitab Keluaran pasal 34 bahwa Tuhan sendirilah yang menjadi penulis loh batu tersebut. Hal yang lebih penting adalah ketika terjadi perbedaan gramatika dan narasi teks, ternyata tidak serta-merta menggugurkan sifat ineransi dari teks. Perbedaan-perbedaan itu dapat ditelusuri, disingkapkan dan dipelajari melalui pendalaman menggunakan pendekatan sumber, penulis dan analisis kesusasteraan. Harus dipahami bahwa naskah-naskah Alkitab ditulis oleh beragam penulis yang memiliki gaya, motivasi dan pendekatan sastra yang sangat khas. Terlebih para penulis tersebut berasal dari Timur Tengah yang dikenal kaya dengan berbagai pendekatan kesusateraan. Pentatukh misalnya, yang secara tradisi dikenal sebagai karya Musa, naskahnya bersumber dari sejumlah kelompok seperti Yahwista, Imam, Elohista dan Ulangan. Masing-masing sumber memiliki kekhasan dan pendekatannya sendiri. Bahkan di dalam karya satu sumber saja, terdapat sejumlah pendekatan yang berbeda tergantung tujuan dan cara pandang yang penulis gunakan untuk memberikan penekanan di dalam menyampaikan sesuatu. Ada kemungkinan bahwa perbedaan di dalam teks Keluaran ayat 1 dan 28 terjadi karena perbedaan penekanan penulis. Semua perbedaan tersebut tidak mengubah fakta

${ }^{27}$ Normal L. Geisler, Biblical Inerrancy: The Historical Evidence (Matthews, NC: Bastion Books, 2013).

${ }^{28}$ R. Albert Mohler et al., Five View on Biblical Inerrancy (Grand Rapids, Michigan: Zondervan, 2013).

${ }^{29}$ Menachem Posner, "Who Engraved the Second Tablets," Chabad.Org, accessed May 15, 2020, https:/www.chabad.org/parshah/article_cdo/aid/1442959/jewish/Who-Engraved-the-Second-Tablets.htm. 
bahwa yang tertulis di atas kedua loh batu, adalah hukum Allah yang berasal dari Allah, ditulis oleh Allah dan menjadi sebuah ketetapan bagi umat-Nya. ${ }^{30}$

\section{REFERENSI}

AFII. The Orthodox Jewish Bible. 4th ed. New Yok: AFI International Publisher, 2011.

Ariyanto, M. Darojat. "Ketidakaslian Kitab Taurat Dalam Perjanjian Lama Dan Empat Injil Dalam Perjanjian Baru (Studi Terhadap Proses Penulisannya)." Ishraqi 4, no. 1 (2008). https://publikasiilmiah.ums.ac.id/bitstream/handle/11617/1002/3. M. Darojat Ariyanto.pdf?sequence $=1 \&$ isAllowed $=y$.

Baker, David L. "Ten Commandments, Two Tablets: The Shape of The Decalogue." Themelios 30, no. 3 (2005): 17

Baker, Joy Don. "The Purpose, Process, and Methods of Writing a Literature Review." AORN Journal 103, no. 3 (2016): 265-269.

Blomberg, Craig L. Can We Still Believe The Bible: An Evangelical Engagement with Contemporary Questions. Grand Rapids: Brazos Press, 2014.

Cole, Alan. Exodus: An Introduction and Commentary. First. Leicester, England: The Tyndale Press, 1973.

Cragg, Kenneth. "Being Christian and Being Muslim: A Personal Debate." Religion 10, no. 2 (1980): 196-208.

Driver, S. R. Book of Exodus. 4th ed. Cambridge: The Syndics of The Cambridge University Press, 1953.

Elliott, J. K., and Bruce M. Metzger. "The Text of the New Testament. Its Transmission, Corruption and Restoration." Novum Testamentum 36, no. 1 (1994): 97.

Ficket, Harold L. Kepercayaan Kaum Baptis: Sebuah Pedoman. Semarang: Seminari Theologia Baptis Indonesia, 1985.

Geisler, Normal L. Biblical Inerrancy: The Historical Evidence. Matthews, NC: Bastion Books, 2013.

Hamilton, Victor P. Exodus - An Exegetical Commentary. Grand Rapids, Michigan: Baker Academic, 2011.

Levin, Christoph. "The Yahwist: The Earliest Editor in the Pentateuch." Journal of Biblical Literature 126, no. 2 (2007): 209-230.

Long, Jason. Biblical Nonsense: A Review of The Bible for Doubting Christians. Lincoln: iUniverse, 2005.

Mohler, R. Albert, Peter Enns, Michael F. Bird, Kevin J. Vanhoozer, and John R. Franke. Five View on Biblical Inerrancy. Grand Rapids, Michigan: Zondervan, 2013.

Owens, John Joseph. Analytical Key to the Old Testament. Volume 1. Grand Rapids, Michigan: Baker Books, 1998.

Posner, Menachem. "Who Engraved the Second Tablets." Chabad.Org. Accessed May 15, 2020. https://www.chabad.org/parshah/article_cdo/aid/1442959/jewish/Who-Engraved-theSecond-Tablets.htm.

Rendtorff, Rolf. "The 'Yahwist' as Theologian? The Dilemma of Pentateuchal Criticism." Journal for the Study of the Old Testament 1, no. 3 (1976): 2-10.

${ }^{30}$ Sonny Zaluchu, "The Digital Mindset as an Approach to Education Forthe Millenial Generation," Proceedings of the Proceedings of the 1st International Conference of Global Education and Society Science, ICOGESS 2019,14 March, Medan, North Sumatera, Indonesia (2020), http://eudl.eu/doi/10.4108/eai.14-32019.2292036 . 
Rennie, David L. "Qualitative Research as Methodical Hermeneutics." Psychological Methods 17, no. 3 (2012): 385-398.

Revell, E. J. "Stress and the WAW 'Consecutive' in Biblical Hebrew." Journal of American Oriental Society 104, no. 3 (1984): 8.

Ridenour, Fritz. Dapatkah Alkitab Dipercaya. Jakarta: BPK Gunung Mulia, 2000.

Sitompul, A.A., and Ulrich Beyer. Metode Penafsiran Alkitab. 14th ed. Jakarta: BPK Gunung Mulia, 2009.

Wauran, Queency Christie. "Kajian Biblika Kecemburuan Allah Terhadap Penyembahan Berhala Berdasarkan Keluaran 20:4-6.” Jaffray 13, no. 2 (2015): 36.

White, James Emery. Can We Trust The Bible? Downers Grove: Intervarsity Press, 2010.

Wright, Rick. Linguistic Evidence for the Pre-Exilic Date of the Yahwistic Source. First. London: T\&T Clarck, 2005.

Zaluchu, Sonny. "The Digital Mindset as an Approach to Education Forthe Millenial Generation." Proceedings of the Proceedings of the 1st International Conference of Global Education and Society Science, ICOGESS 2019,14 March, Medan, North Sumatera, Indonesia (2020). http://eudl.eu/doi/10.4108/eai.14-3-2019.2292036.

Zaluchu, Sonny Eli. "Strategi Penelitian Kualitatif Dan Kuantitatif Di Dalam Penelitian Agama." Evangelikal: Jurnal Teologi Injili dan Pembinaan Warga Jemaat 4, no. 1 (2020): 28-38.

"The Chicago Statement on Biblical Inerrancy." Master's Seminary Journal 1, no. Spring (2014): $1-10$. 